\title{
Filosofia do direito em perspectiva genealógica
}

\author{
Luiz Felipe Xavier Gonçalves*
}

Resumo: Neste artigo, investigamos a concepção nietzschiana para a "filosofia do direito". Assim, apresentamos a hipótese de que o autor possui uma conceituação heterodoxa acerca da filosofia do direito, podendo ser entendida numa perspectiva genealógica. Para coloca-la à prova, analisamos um fragmento póstumo de 1883 em três momentos: incialmente, apresentamos a crítica nietzschiana à filosofia do direito de Rudolf von Jhering. Em um segundo momento, indicamos que Nietzsche sinaliza uma perspectiva genealógica como novo método para ela. Por fim, apresentamos o que ele entende como um exemplo de erro interpretativo dos filósofos do direito: a significação da punição.

Palavras-chave: Genealogia da moral, filosofia do direito, genealogia do direito, castigo.

Analisando os textos de Nietzsche, observamos que a expressão "filosofia do direito" (Philosophie des Rechts) aparece, de modo explícito, em apenas um momento. Apesar de ser referência única, o texto em que ela aparece apresenta uma densa crítica de Nietzsche ao modo habitual de se fazer filosofia do direito dentre seus contemporâneos. Trata-se de um fragmento póstumo do verão de 1883: ${ }^{1}$

\footnotetext{
* Professor do Centro Universitário Brasileiro - UNIBRA e Colégio Salesiano Recife, PE, Brasil. Correio eletrônico: felipexter@hotmail.com ORCID https://orcid.org/0000-0001-6480-9261

1 Em <http://www.nietzschesource.org/\#eKGWB/NF-1885,42[8]> há uma nota explicando que o fragmento [Nachlass/FP agosto-setembro 1885, 42 [8], KSA 11.697] é uma duplicata do de 1883.
} 
Ah, a filosofia do direito! Esta é uma ciência que, como todas as ciências morais, não está nem em seu início! Ainda não se reconhece, por exemplo entre os juristas de pensamento mais livre, o significado mais antigo do castigo - se ignora completamente: e enquanto a ciência do direito não se funda em uma base nova, ou seja, sobre a história e o estudo comparado dos povos, permanecerá com essa miserável luta de abstrações fundamentalmente erradas, que passam hoje por "filosofia do direito" e que são todas deduzidas do homem atual. Mas este homem atual é algo tão enredado, também em suas avaliações jurídicas, que permite as interpretações mais distintas (Nachlass/FP verão 1883, 8 [13], KSA 10.334). ${ }^{2}$

$\mathrm{Na}$ tentativa de compreender o fragmento, auxiliados por outros textos de sua obra publicada e póstuma, trazemos a hipótese de que o autor possui uma concepção que aqui chamaremos de heterodoxa acerca da filosofia do direito e que ela pode ser vista sob uma perspectiva genealógica. Para tanto, analisaremos o fragmento póstumo em três extratos, indicando que Nietzsche:

I. critica a filosofia do direito de sua época, sobretudo - no nosso entender - as formulações de Rudolf von Jhering;

II. estabelece um método para as investigações da disciplina, podendo ser compreendido em perspectiva genealógica;

III. e indica um exemplo de erro interpretativo cometido pelos filósofos do direito de sua época, qual seja, a significação da punição, do castigo.

\section{Crítica à tradicional acepção de filosofia do direito}

Para compreendermos a crítica nietzschiana acerca da "maneira tradicional" de se entender a filosofia do direito, podemos ir a dois trechos distintos e posteriores ao fragmento acima citado. Em

2 Para as citações da obra de Nietzsche, utilizamos as traduções de Rubens Rodrigues Torres Filho (RRTF) e de Paulo César de Souza (PCS). Quando não houver qualquer indicação, a tradução é de nossa responsabilidade.

Cad. Nietzsche, Guarulhos/Porto Seguro, v.41, n.3, setembro-dezembro $2020 \mid 167$ 
1884, ele escreve: “Com a finalidade, todavia, não se demonstra a existência do fim. Com o fato de que em todo costume e em todo direito há um fim, não se mostra que desde a sua emergência se persiga esse fim, e frequentemente é inadequado com relação aos meios de tal fim" (Nachlass/FP verão-outono 1884, 26[134], KSA 11.185). Como observado, já aqui Nietzsche descreve bem que o fato de se encontrar uma finalidade no direito não significa que ela sempre esteve lá. A partir disso, podemos concluir que a um direito podem ter sido incorporadas as diversas finalidades que ele possui. Em resumo, o que o autor esboça no fragmento acima é sua crítica a uma espécie de finalismo que as diversas "filosofias do direito" de sua época ${ }^{3}$ defendiam como intrínsecas ao conceito de direito.

Mas é em Genealogia da moral que ele ataca de modo mais incisivo e radicaliza seu pensamento:

Mas a "finalidade do direito" é a última coisa a se empregar na história [do surgimento] do direito: pois não há princípio mais importante para a ciência histórica do que este, que com tanto esforço se conquistou, mas que também deveria estar realmente conquistado - o de que a causa [do surgimento] de uma coisa e a sua utilidade final, a sua efetiva utilização e inserção em um sistema de finalidades, diferem toto coelo (GM/GM II 12, KSA 5.313. PCS, modificada).

Esse trecho é uma crítica ao livro homônimo de Rudolph von Jhering, ${ }^{4}$ a primeira parte publicada em 1877, sobretudo se notar-

3 Para esse tema, é digno de nota a leitura de Metodologia da ciência do direito, de Karl Larenz. Na primeira seção do livro, ele dedica remontar a parte "histórico-crítica" da "Teoria do direito e metodologia na Alemanha desde Savigny", justamente nos séculos XIX e XX. Ainda nessa parte, ele inscreve as discussões do XIX acentuando, sobretudo, as teorias de Savigny e de Jhering. Ver: Larenz, 1991.

4 Citar todas as nuances em que se envolvem o pensamento de Rudolf von Jhering (1818-1892) não é o objetivo do presente artigo. Expomos um comentário que nos ajuda a situar o cenário da discussão jurídica do século XIX: “A doutrina alemã do direito civil era fundamentalmente diferente da Escola Francesa de Exegese. [...]. [A doutrina alemã via o direito] como uma luta entre forças e interesses opostos. Para [os alemães], o direito era acima de tudo um produto social e um instrumento para a ação social, em vez do domínio privilegiado dos eruditos; sua doutrina ficou conhecida como Interessenjurisprudenz [Jurisprudência dos interesses], opondo- 
mos a indicação da expressão "finalidade do direito", que ele faz questão de colocar entre aspas. Essa relação já tinha sido pontuada por Rubens Rodrigues Torres Filho, em uma nota de rodapé das Obras incompletas,${ }^{5}$ mas não foi o objetivo do tradutor explorar a relação, o que aqui nos propomos a realizar. Além disso, há ao menos três registros sobre Jhering nos textos nietzschianos: $1^{\circ}$. em 31 de julho de 1879, Nietzsche enviou uma carta ao amigo Franz Overbeck e, ao fim dela, pede que providenciasse um exemplar "do último livro de Jhering, A finalidade do direito" (KSB 5.432); $2^{\circ}$. em 12 de agosto de 1879, agradeceu o exemplar que fora enviado, explicando a Overbeck que se tratava apenas do primeiro volume da obra, não dela completa; mesmo assim, recomendou a leitura a todos (cf. KSB 5.434); $3^{\circ}$. em 1883, fez um pequeno comentário a respeito do cerne do conceito de direito do autor, que abordaremos mais à frente no texto (cf. Nachlass/FP primavera-verão 1883, 7 [69], KSA 10.265).

Realizando uma breve análise dos pontos centrais do livro, podemos dizer que Jhering apresenta uma explicação sobre a "lei de finalidade" como pressuposto básico para sua tese acerca do direito. Admitindo a existência e validade da lei da causalidade, segundo a qual "toda modificação no mundo sensível é consequência de outra precedente" $"$, ele defende que a vontade também se submete a tal lei e que, nesse caso, ela é de natureza psicológica. Desse modo, ele a chama de lei psicológica de causalidade ou, simplesmente, de lei de finalidade pelo seguinte motivo: "A pedra não cai com a finalidade de cair, mas porque deve, isto é, por lhe ter sido retirado o apoio; o homem, entretanto, que age, fá-lo não em

\footnotetext{
-se à Begriffsjurisprudenz [Jurisprudência dos conceitos]. Era necessário, portanto, estabelecer quais os objetivos sociais a serem alcançados com a ajuda do direito; daí o título da obra radical de Rudolf von Jhering [...], Der Zweck im Recht (1877) e seu lema 'A finalidade é a criadora de todo direito'. Von Jhering começara como um romanista tradicional, mas tornou-se insatisfeito com o raciocínio lógico abstrato e envolveu-se nos problemas sociais de seu tempo, o que o conduziu a formular seu próprio conceito de direito" (Caenegem 1999, p. 223-224).

5 Trata-se da nota ${ }^{\circ} 18$ em: Nietzsche 1974, p.315.

6 Jhering, 2002, p.15.
}

Cad. Nietzsche, Guarulhos/Porto Seguro, v.41, n.3, setembro-dezembro $2020 \mid 169$ 
razão de um 'porquê', mas de um 'para quê' - para, desta forma, conseguir algo". 7 Todo o restante do primeiro capítulo é, na verdade, a sua tentativa de fundamentar tal lei.

Aqui se percebe que há uma contraposição basilar entre as ideias de ambos os autores: trata-se dos pressupostos de Jhering sobre a vontade e a lei de finalidade, que constituem a base de sua teoria acerca do direito. Tais temas, vontade e finalidade, são caros a Nietzsche, mas sob uma outra perspectiva. Enquanto Jhering realiza uma vinculação entre ambos, prevendo uma finalidade intrínseca entre eles, o autor do Zaratustra os contrapõe radicalmente: "Mas todos os fins, todas as utilidades, são apenas sinais de que uma vontade de potência se tornou senhora de algo menos poderoso e, a partir de si, imprimiu-lhe o sentido de uma função" (GM/GM, II, 12, KSA 5.314, RRTF). Sobre a "vontade de potência", sabemos que se trata de um conceito formulado como explicação cosmológica sobre o Universo, em que Nietzsche defende ser um impulso de domínio, de querer exercer-se e afirmar-se que sempre busca mais potência. A diferença fundamental é que Nietzsche não admite um telos na vontade de potência e, não havendo finalidade inscrita, esta última atuará como um "impulso cego", sempre buscando mais potência, mesmo que isso seja prejudicial à sua mera conservação.

Compreendemos, então, a razão de Nietzsche não ver sentido em uma "finalidade do direito", ainda que esta fosse descrita como conservação. Na verdade, ele tem por base que o direito e o Estado surgiram como atuação e exercício da vontade de potência dos mais fortes sobre os fracos, mas não com o fito de estabelecer uma ordem e garantir a manutenção da paz e da sociabilidade. Essa ideia seria uma apropriação posterior que surgiu, por fim, como uma resposta tardia e silenciamento da verdadeira origem e manutenção violentas do Estado (cf. GM/GM, II, 16-17 KSA 5.321-324).

A partir disso, percebemos que Jhering amplia a questão sobre a finalidade do direito, levando-a à questão sobre a finalidade do Estado:

7 Jhering, 2002, p.15. 
[A] A organização social da coação [...] significa o mesmo que Estado e Direito. O Estado é a sociedade como detentora da força de coação regulada e disciplinada. A quintessência dos princípios que o norteiam nesse sentido, a disciplina da coação, é o direito. Ao definir o Estado deste modo, não quero dizer que esta fórmula exaure sua essência, não quero afirmar que ele nada mais seja do que isso. Acabo de constatar justamente o contrário, quando salientei o quanto o Estado, ao longo de sua evolução, se enriquece cada vez mais de finalidades que até então lhe haviam sido estranhas. [B] Todavia, por diversos e [numerosos] que possam ser esses fins, que ele, Estado, já abarcou e que ainda abarcará, existe um objetivo que sobreleva todos os outros, uma meta que o acompanha desde o princípio, sim, uma finalidade que até mesmo o fez nascer e que jamais pode ausentar-se. Trata-se da finalidade do direito, a formação e asseguramento do direito. Todos os outros propósitos do Estado passam para segundo plano diante deste, só emergindo, historicamente, quando aquela tarefa primeira e essencial já estiver satisfeita, sendo ela pressuposto necessário para as outras. Assim, o cultivo do direito é a função vital do Estado. ${ }^{8}$

Para melhor análise, como se percebe, dividimos o trecho em dois extratos [A e B]. Ao que parece, no primeiro trecho [A], Jhering define o direito e o Estado como formas de organização de uma coação, detentora de força para regular uma sociedade. Vemos uma aproximação com o texto nietzschiano no trecho: “o Estado [...] se enriquece cada vez mais de finalidades que até então lhe haviam sido estranhas" (Jhering 2002, p.15), pois Nietzsche defende que há uma "síntese de sentidos", ou seja, finalidades que vão surgindo com o tempo, sempre reinterpretados e agregados em momentos posteriores (cf. GM/GM II 12-13, KSA 5.313-318). Talvez a discórdia, nesse trecho, seja em relação a uma evolução, refutada pelo autor da Genealogia da moral.

Mas a discordância central entre eles é o trecho posterior [B], pois Jhering insiste na ideia de que há uma finalidade "originária" para a existência do Estado. Ou seja, apesar de considerar uma pluralidade de sentidos para a existência do direito, assim como

8 Jhering, 2002, p. 211-212. 
pensa Nietzsche, Jhering é defensor de outra concepção: o Estado existe para "cultivar", manter e proteger a instituição do direito; toda e qualquer finalidade está, por decorrência, intrinsecamente ligada a esta. Nesse ponto, é interessante perceber que um dos argumentos de Jhering para a defesa da existência de uma "finalidade" no direito se baseia em uma questão filológica, qual seja, de que "direito" se remete a algo "correto":

A expressão 'correto' encerra a ideia de direção, i.e., de caminho que alguém tem de percorrer para alcançar seu fim - a finalidade. É a mesma ideia que o idioma aplicou de modo tão abundante [...]: no âmbito do direito (em nossa língua alemã, Richter, Richtsteig, Weg Rechtens, recht $=$ reht, i.e., reto - regere, rex, regula, rectum, regieren, dirigere, directum, diritto, derecho, droit). Todas essas expressões não foram derivadas do caráter peculiar do direito como tal, mas daquilo que o direito, como disciplinamento da conduta humana, tem em comum com todo comportamento: a observância do caminho reto, direito, correto; a direção ao alvo, o fim. ${ }^{9}$

Esse trecho nos faz lembrar que Nietzsche lança mão do mesmo instrumento investigativo em diversos momentos. Pontuamos aqui, sobretudo, o trecho da primeira dissertação da Genealogia da moral em que o autor averigua "a proveniência do conceito e juízo 'bom"' (GM/GM, I, 2, KSA 5.258 (RRTF)) e, nas seções seguintes (cf.GM/GM, I, 4-5, KSA 5.261-264), chega a conclusões contrárias às de Jhering. Nietzsche afirma que, através do pathos da distância, os nobres deram a si mesmos o direito senhorial de criar valores (cf. GM/GM, I, 2, KSA 5.259). Jhering, contudo, postula algo diametralmente oposto: "Tudo o que brota sobre o solo do direito, nasceu através de sua finalidade e em função de sua finalidade. Todo o direito outra coisa não é senão uma única criação teleológica" ${ }^{10}$

9 Jhering, 2002, p.291.

10 Jhering, 2002, p.294 - destaque nosso. 
Ainda assim, parece-nos que resta a resposta de Jhering para a existência do direito, que é o mesmo de sua finalidade. Ele responde estabelecendo um círculo vicioso: a finalidade do direito é "a forma de asseguramento das condições vitais da sociedade, produzido através do poder coercitivo do Estado" (Jhering, 2002, p.294). Aqui pontuamos que, já em 1883, Nietzsche havia compreendido isso e faz a seguinte anotação: “ $\mathrm{O}$ 'direito', segundo Jhering, é o asseguramento das condições vitais da sociedade sob a forma de coerção" (Nachlass/FP primavera-verão 1883, 7 [69], KSA 10.265). Tais condições vitais da sociedade dizem respeito, unicamente, às exigências da vida. Nessa questão, pontuamos que há certa semelhança com as definições de Nietzsche sobre o critério do procedimento genealógico. Há que se notar, contudo, que Jhering defende uma concepção de vida ligada a uma ideia de "bem estar", algo fortemente rechaçado por Nietzsche:

Viver, entretanto, não significa simples existência física. Mesmo e, mais pobre e mais insignificante exige da vida mais do que mera conservação: almeja bem-estar, não mera existência, e por mais diversa que seja sua ideia de bem-estar [...], por mais diversa que seja sua representação, sua imagem ideal da vida constitui, para ele, o parâmetro pelo qual mede o valor de sua real existência; a realização deste ideal constitui o objetivo de toda a sua aspiração, a alavanca de sua vontade (Jhering, 2002, p.294).

Por fim, é possível enxergar, entre as teses de Nietzsche e de Jhering, pontos de concordâncias e discordâncias, como acima indicamos. Acentuamos que Nietzsche, ao realizar a leitura do primeiro volume da obra $A$ finalidade do direito, estabeleceu um contraponto à base do argumento de Jhering sobre a finalidade em diversos momentos de sua obra e, sobretudo, na segunda dissertação da Genealogia da moral. Enquanto, para o jurista, o direito e, por consequência, o Estado existem com a finalidade de assegurar as condições de possibilidade de existência da sociedade, para o filósofo, origem e finalidade do direito são problemas distintos e dissociáveis. Assim, na concepção de Nietzsche, o direito surge 
como puro exercício da força e, com o seu desenvolvimento, os procedimentos que garantem o direito e a ordem são inseridos em um sistema de finalidades, movimento posterior, portanto.

\section{O procedimento genealógico como novo método para a ciência e a filosofia do direito}

Tendo visto os contrapontos de Nietzsche às concepções de Jhering, cabe agora compreendermos o que o autor propõe como nova base e método para a filosofia do direito. Isso podemos encontrar no seguinte trecho: "enquanto a ciência do direito não se funda em uma base nova, ou seja, sobre a história e o estudo comparado dos povos, permanecerá com essa miserável luta de abstrações fundamentalmente erradas, que passam hoje por "filosofia do direito" (Nachlass/FP verão 1883, 8 [13], KSA 10.334).

Antes de adentrarmos nos aspectos centrais do trecho, é importante acentuarmos um aspecto sobre a fortuna crítica. Em 1907, Josef Kohler publica Nietzsche und die Rechtsphilosofie, ${ }^{11}$ realizando uma análise das sessões 417 a 449 do volume XIII do Nietzsche's Werke, coordenados por Elisabeth Förster-Nietzsche. No seu texto, Kohler afirma que Nietzsche era aquele que "reconheceu, há mais de 20 anos, que a filosofia do direito só pode se basear no conhecimento da história humana". ${ }^{12} \mathrm{O}$ fato é que nos trechos indicados por Kohler, nem mesmo em todo o volume por ele utilizado, não há o fragmento de 1883 que apontamos como base. Isso nos leva a crer que, apenas pelos trechos lá dispostos, Kohler encontra os elementos necessários para apresentar a mesma ideia: de que Nietzsche inovava em suas afirmações a respeito da filosofia do direito.

11 cf. Kohler, 1907, p.355-360.

12 Kohler, 1907, p.360. 
Filosofia do direito em perspectiva genealógica

Retomemos a nossa questão. É bem verdade que o "procedimento genealógico", aqui entendido como uma "metodologia" que investiga criticamente a proveniência dos valores morais, só é indicado por Nietzsche enquanto tal apenas em Genealogia da moral. No Prólogo da obra, indagando-se acerca de seus "pensamentos sobre a procedência de nossos preconceitos morais" (GM/GM, Prólogo, 2, KSA 5.248, RRTF), ele nos fornece sua perspectiva: parte de um pressuposto histórico acerca da moral e entende-a como algo inscrito temporalmente - como algo criado em determinadas circunstâncias e não como algo absoluto, de origem eterna.

Assim, enunciando a sua "nova exigência" para a crítica da moral (cf. GM/GM, Prólogo, 6, KSA 5.253), nos fornece a dupla tarefa genealógica: questionar a procedência histórica dos valores morais, para saber as perspectivas de sua criação, e realizar a avaliação desses mesmos valores. Mas, para realizar a avaliação de valores, há sempre que se ter um ponto referencial da análise. Nietzsche admite, por fim, um critério que fuja dos próprios referenciais e domínios da moral, para não cair no risco de tornar sua argumentação um "círculo vicioso". É nesse contexto que surge um critério fisiológico para tal análise: um critério que evidencia em que medida uma determinada moral favorece a obstrução ou a promoção da vida (cf. GM/GM, Prólogo, 3, KSA 5.249-250).

Se observarmos, numa análise geral e retrospectiva de sua obra, podemos notar que já o texto de 1883 nos indica alguns elementos que nos ajudam a reforçar a tese de que há o desenvolvimento do "procedimento genealógico" em sua obra. ${ }^{13}$ Desse modo, percebemos que, nesse fragmento de 1883, o novo método indicado por Nietzsche à "ciência e à filosofia do direito" é baseado na "história e no estudo comparado dos povos", algo bem próximo de alguns aspectos que acima elencamos.

13 Acompanhamos o pensamento de Céline Denat. A autora afirma que a Genealogia da moral é a culminância de duas fases anteriores, a de Humano, demasiado humano (Contribuição à história dos sentimentos morais) e a de Para além de bem e mal (Contribuição à história natural da moral). (cf. Denat 2016, p. 7-42).

Cad. Nietzsche, Guarulhos/Porto Seguro, v.41, n.3, setembro-dezembro $2020 \mid 175$ 
Essa perspectiva histórica apresenta-se, então, como parte necessária à sua crítica aos valores ocidentais e, nesse sentido, ela enseja a investigação histórica da moral nos mais diversos povos. Assim, como apontado anteriormente, um estudo comparado das variadas morais foi indicado por Nietzsche como parte da genealogia. Como exemplo disso, percebemos que em Para além de bem e mal, na seção 260, o autor apresentou os dois tipos básicos da moral - a moral dos senhores e a moral dos escravos - como resultado de uma "perambulação pelas muitas morais" (JGB/BM 260, KSA 5.208, PCS). E, depois, quando de sua sinalização do critério de "saúde" da vida como nova referência avaliativa da moral, ele diz: "Sobre isso encontrei e aventurei comigo mesmo muitas sortes de resposta, distingui tempos, povos graus hierárquicos dos indivíduos [...]" (GM/GM, Prólogo 3, KSA 5.250, RRTF).

Nesse sentido, compreendemos que a história e o estudo comparado dos povos são apontados por Nietzsche como um novo método, só que agora também referente à filosofia do direito. Além disso, podemos destacar outro aspecto que nos aponta uma crítica mais acentuada à tradicional acepção sobre a "filosofia do direito". Se no referido texto póstumo de 1883, Nietzsche define-a como uma "ciência moral", podemos inseri-la na crítica que ele realiza em Para além de bem e mal, especificamente o capítulo quinto: "Contribuição à história da moral".

Basta lembrarmos que, em específico, na seção 186, o autor mostra-se contrário à "ciência da moral" que, em sua opinião, se apresenta arrogante e pretensiosa por buscar uma "fundamentação da moral". Contra a tarefa de fundamentação da moral, Nietzsche sugere a "tipologia da moral", ou seja: "reunião de material, formulação e ordenamento conceitual de um imenso domínio de delicadas diferenças e sentimentos de valor que vivem, crescem, procriam e morrem - e talvez tentativas de tornar evidentes as configurações mais assíduas e sempre recorrentes dessa cristalização viva" (JGB/BM 186, KSA 5.105, PCS). É apenas com base na tipo- 
logia que se teria "em vista os verdadeiros problemas da moral - os quais emergem somente na comparação de muitas morais" (JGB/ BM 186, KSA 5.105, PCS).

Ou seja, nos parece que, analisando toda a questão do procedimento genealógico em conjunto, como conceito que aos poucos foi tomando forma nas conceituações de Nietzsche, podemos concluir que o fragmento de 1883 traz os elementos para o colocarmos dentro desse registro. É nesse sentido que compreendemos que, para não se cair nas abstrações da tradicional filosofia do direito, Nietzsche indica a realização de algumas das etapas que depois foram incluídas como parte do processo investigativo do "procedimento genealógico". Assim, na visão de conjunto, podemos realizar as etapas do procedimento como novo método da "filosofia do direito".

\section{Um exemplo de erro interpretativo da tradicional "filosofia do direito" - Genealogia do castigo}

Analisemos, por fim, o último trecho do fragmento póstumo em questão: "Ainda não se reconhece, por exemplo entre os juristas de pensamento mais livre, o significado mais antigo do castigo - se ignora completamente" (Nachlass/FP verão 1883, 8 [13], KSA 10.334). Ora, aqui o autor nos diz, sendo propositivo, o que em sua concepção é um tema apropriado à investigação da disciplina. Ele defende, assim, que a filosofia do direito foi erroneamente interpretada pelos seus representantes tradicionais, acusando-os de integrar uma concepção finalista na mesma, compreendendo-a a partir de uma concepção metafísica. Portanto, compreender a significação da punição, afastando-a das tradicionais abstrações conceituais, é uma das tarefas da filosofia do direito nietzschiana. Assim, o que Nietzsche aqui indica, ele de fato o realiza na Genealogia da moral. Em vários parágrafos da segunda dissertação, o 
autor desenvolve uma espécie de genealogia do castigo, mostrando uma aplicação de seu procedimento genealógico a um tema caro ao direito. Ele assim argumenta:

sobre a origem e a finalidade do castigo - dois problemas distintos, ou que se deveria distinguir: infelizmente se costuma confundi-los. Como procederam neste caso os genealogistas da moral? De modo ingênuo, como sempre -: descobrem no castigo uma 'finalidade' qualquer, por exemplo a vingança, ou a intimidação, colocam despreocupadamente essa finalidade no começo, como causa fiendi [causa de origem] do castigo, e - é tudo (GM/GM, II, 12, KSA 5.313, PCS).

Perscrutando a relação entre origem e finalidade do castigo, Nietzsche chega à conclusão de que o castigo só pode ser compreendido sob a ótica de outros institutos morais e jurídicos que aqui estão intimamente ligados, quais sejam: a relação contratual entre credor e devedor; a complementaridade entre os conceitos de obrigação, dívida e culpa; e o modo como surge o direito de punir.

Fazendo uma análise da argumentação de Nietzsche sobre a procedência do Estado, na Genealogia da moral, o autor argumenta que o homem foi obrigado a forjar-se como "um animal capaz de fazer promessas" (GM/GM, II, 1, KSA 5.291, PCS) e que, para tanto, foi necessário se "construir uma memória naquele que promete" (GM/GM, II, 5, KSA 5.299, PCS). No fim de um longo processo de "tornar o homem até certo ponto necessário" (GM/GM, II, 2, KSA 5.293, PCS), um dos resultados foi o surgimento da "má consciência", a consciência de culpa ou, como disse o próprio Nietzsche, "o sofrimento do homem com o homem, consigo" (GM/GM, II, 16, KSA 5.322, PCS). A tese de Nietzsche é de que tudo isso só foi possível "com a ajuda da '[eticidade] do costume' e da camisa de força social" (GM/GM, II, 2, KSA 5.293, PCS, modificada). Disso, segue-se que a má consciência e o "conceito de culpa" surgem tardiamente. A relação que os antecede, na verdade, é uma relação material baseada no "conceito de dívida". Tratemos desse aspecto. 
Novamente acusando um erro interpretativo sobre o que seria a origem de alguns institutos jurídicos, Nietzsche escreve:

Esses genealogistas da moral teriam sequer sonhado, por exemplo, que o grande conceito moral de "culpa" teve origem no conceito muito material de "dívida"? Ou que o castigo, sendo reparação, desenvolveuse completamente à margem de qualquer suposição acerca da liberdade ou não-liberdade da vontade? [...]. De onde retira sua força esta ideia antiquíssima, profundamente arraigada, agora talvez inerradicável, a ideia da equivalência entre dano e dor? Já revelei: na relação contratual entre credor e devedor, que é tão velha quanto a existência de "pessoas jurídicas", e que por sua vez remete às formas básicas de compra, venda, comércio, troca e tráfico (GM/GM, II, 4, KSA 5.297, PCS).

Algo central que aqui trazemos é que o conceito moral de culpa possui sua origem no conceito material de dívida. Na língua alemã, como se pode notar, essa relação se mostra mais evidente: culpa e dívida, dois conceitos de campos distintos, são expressas pela mesma palavra: Schuld. Na argumentação nietzschiana, percebemos que o conceito de "relação contratual entre credor e devedor" (portanto, uma relação que gera vínculos obrigacionais, dívidas) foi aos poucos sendo transmutado de um conceito material e jurídico para um conceito moral, justamente pela utilização dos procedimentos do castigo com o fito de reparar tal dívida, estabelecendo assim uma concepção de justiça que se remete a uma equivalência entre dano e dor.

Nesse ponto, é preciso antecipar que a afirmação de Nietzsche relacionando os conceitos de "direito pessoal [...] troca, contrato, débito, direito, obrigação, compensação" (GM/GM, II, 8, KSA 5.306, PCS) encontra, em certo sentido, respaldo na teoria do direito. Se recorrermos especificamente à noção de direito das obrigações $^{14}$, perceberemos que aqui se estabelece uma ligação, ao que

14 A ideia que caracteriza a obrigação é a de vínculo. Obrigação provém de "ob + ligare", apresentando a noção de que se trata de "ligar (ligare) de modo estreito (ob)". Quando os autores se referem, nos tratados de direito privado, à obrigação civil, essa ligação é descrita como um vínculo de direito entre credor e devedor. No que diz respeito especificamente ao

Cad. Nietzsche, Guarulhos/Porto Seguro, v.41, n.3, setembro-dezembro $2020 \mid 179$ 
já no antigo direito dos romanos se chamava vinculum juris (vínculo jurídico). ${ }^{15}$

\section{Atentemos ao postulado de Jhering:}

Exemplificação pelo direito romano - Pela concepção romana antiga, a mera promessa (pactum nudum) não gera ação, i.e., a ideia da força vinculante da promessa é estranha naquele tempo. A cogência jurídica da promessa, i.e., a ação (actio) acha-se condicionada pelo fato de o credor haver prestado algo ao devedor. A causa obrigacional da promessa assenta na prestação (res) pela outra parte. Ninguém promete, destarte, sem que deva fazê-lo, ou seja, deve para, por sua vez, receber algo. Toda promessa é, consequentemente, a promessa de uma prestação ulterior em virtude de uma prestação anterior adquirida (ou, juridicamente, suposta como adquirida. Somente pelo elemento substancial do haver, propriamente, é que ela ganha força vinculante. [...]. Devedor (debitor) é aquele que tem algo de outrem (dehabere $=$ debere, debitor); credor (creditor), aquele que deu algo (duere $=$ dare, creduere, creditor $)$; dívida, o dinheiro dado ao devedor (aes alienum). Todos os três conceitos: devedor, credor, dívida, remontam conforme sua forma gramatical à representação do fato de se ter algo de outrem. ${ }^{16}$

Apesar de Nietzsche não discutir especificamente esse detalhe do vocabulário jurídico - de que a promessa não basta, sendo necessária a tradição, a entrega da coisa - há interessantes paralelos a serem traçados. Enquanto Jhering parece colocar a promessa em segundo plano, bem sabemos que logo no início da segunda dissertação da Genealogia da moral o nosso autor torna central e

direito pessoal, termo inclusive citado por Nietzsche, temos a compreensão de que o vínculo obrigacional dá origem a um direito pessoal, um direito contra uma pessoa - que é devedora -, que lhe opõe um direito real, ou seja, um direito que incide diretamente sobre uma coisa (res). Sobre essa questão, trazemos a lição de Pontes de Miranda: “Em sentido estrito, 'obrigação' é a relação jurídica entre duas (ou mais) pessoas, de que decorre a uma delas, ao debitor, ou a algumas, poder ser exigida, pela outra, creditor, ou outras, prestação. Do lado do credor, há a pretensão; do lado do devedor, a obrigação" (Pontes de Miranda, 2013, p.12).

15 "No direito romano, as relações jurídicas do direito das obrigações eram mais estritamente pessoais do que hoje. O vinculum juris prendia as pessoas do devedor e do credor, de modo que o objeto da prestação era secundário" (Pontes de Miranda, 2013, p.8).

16 Jhering 2002, p.187. 
basilar o tema da "capacidade de fazer promessas". Nietzsche não discute o detalhe, se há ou não o peso da entrega da coisa, objeto da restituição da promessa feita, mas sim enfatiza o papel da promessa. Contudo, há que se notar que ele afirma que a "relação contratual entre credor e devedor [...] [se] remete às formas básicas de compra, venda, comércio, troca e tráfico" (GM/GM, II, 4, KSA 5.298 , PCS) e que o "devedor, para infundir confiança em sua promessa de restituição, para garantir a seriedade e a santidade de sua promessa, para reforçar na consciência a restituição como dever e obrigação, por meio de um contrato empenha ao credor, para o caso de não pagar, algo que ainda "possua '[...]" (GM/GM II 5, KSA 5.299, PCS - destaques nossos). Destacamos, assim, que Nietzsche considera a coisa a ser restituída, portanto, a coisa como objeto da promessa. Nesse sentido, mesmo sem ir ao vocabulário técnico do direito para tratar da presença ou ausência da coisa para a haver a possibilidade de uma ação, Nietzsche considera que há sim algo que é objeto central da promessa.

Nietzsche parece afirmar que a procedência do direito se dá perante as relações contratuais entre credor e devedor, portanto, $o$ direito remontaria a relações concretas, relações instituídas entre as pessoas, pelos próprios membros do que, posteriormente, seria definido como sociedade. É em Humano, demasiado humano que o autor nos dá uma primeira indicação do que estamos a defender: "Sem contrato, não há direito" (MAI/HHI, 446, KSA 2.290). Posteriormente, em Humano, demasiado humano II, $O$ andarilho e sua sombra, ele prossegue no mesmo sentido: "Origem dos direitos. - Os direitos remontam primeiramente à tradição, e a tradição, a uma convenção" (WS/AS 39, KSA 2.569-570, PCS). Nesse momento, o termo utilizado por Nietzsche é Abkommen [acordo], que já comporta um sentido de contrato, se o tomarmos como um acordo de vontade.

Contudo, mais tarde, em Aurora, Nietzsche é mais expressivo sobre o ponto que buscamos defender. Na seção 112, ele nos dá 
sua "Contribuição à história natural do dever e do direito": "Nossos deveres - são os direitos de outros sobre nós. De que modo eles os adquiriram? Considerando-nos capazes de fazer contrato e dar retribuição, tomando-nos por iguais e similares a eles, e assim nos confiando algo, nos educando, repreendendo, apoiando" (M/A 112, KSA 3.100, PCS). Já aqui, o termo utilizado por Nietzsche é Vertrags, ou seja, contrato. Posteriormente, em um fragmento póstumo de 1886, ele afirma: "O direito surge apenas onde há contratos" (Nachlass/FP verão 1886 — outono 1887, 5[82], KSA 12.221).

Se juntarmos todos os aspectos do que aqui estamos abordando, ou seja, a relação entre credor e devedor, com o consequente estabelecimento de um vínculo obrigacional entre as duas partes, julgamos ter os elementos necessários para defender a tese de que, no que diz respeito ao surgimento do direito, Nietzsche enxerga-o como originado a partir de um "contrato". ${ }^{17}$

Baseados na seção 17 da segunda dissertação de Genealogia da moral, procedemos a uma interpretação que buscou compreender o texto de Nietzsche enquanto uma espécie de "teoria contratualista heterodoxa", pois, ao afirmar que um determinado povo teria se utilizado da força para imprimir uma organização social a uma massa informe, o autor estaria apenas retirando a sombra de um sentimentalismo da ideia de uma ordem estatal instituída por meio de um acordo de vontade entre todos os homens. Assim, ele teria renovado a concepção do termo: ao invés de o Estado ter nascido pelo acordo de vontade de todos os homens, a maneira moderna e tradicional de se compreender o contratualismo, o contrato teria sido estabelecido entre os que, fortes e guerreiramente organizados, teriam forçado os demais à organização social.

Assim sendo, também o direito teria surgido com base no contrato estabelecido entre os fortes, entre aqueles que teriam suficiente força para estabelecer promessas entre si e para submeter

17 Aqui pontuamos o debate que esboça as convergências e divergências entre Nietzsche e a tradição contratualista em: Melo Neto; Santos, 2018, p.31-53. 
os mais fracos. Dois trechos de Genealogia da moral, em nosso entender, nos ajudam a corroborar a tese. O primeiro deles: "justiça é a boa vontade, entre homens de poder aproximadamente igual, de acomodar-se entre si, de 'entender-se' mediante um compromisso - e, com relação aos de menor poder, forçá-los a um compromisso entre si" (GM/GM, II, 8, KSA 5.306-307, PCS).

No segundo trecho, ao tratar da "origem da justiça", Nietzsche combate mais um da série de "erros interpretativos" que temos aqui abordado. Ele rechaça a possibilidade de se ligar o ressentimento à origem e fonte da justiça. Para isso, descreve:

a qual esfera sempre pertenceu até agora a administração do direito, e também a própria exigência de direito? À esfera dos homens reativos, talvez? Absolutamente não; mas sim à dos ativos, fortes, espontâneos, agressivos. Historicamente considerado, o direito representa [...] justamente a luta contra os sentimentos reativos, a guerra que lhes fazem os poderes ativos e agressivos, que utilizam parte de sua força para conter os desregramentos do pathos reativo e impor um acordo. Em toda parte onde se exerce e se mantém a justiça, vemos um poder mais forte que busca meios de pôr fim, entre os mais fracos a ele subordinados (grupos ou indivíduos), ao insensato influxo do ressentimento, seja retirando das mãos da vingança o objeto do ressentimento, [...] seja imaginando, sugerindo ou mesmo forçando compromissos [...] (GM/GM, II, 11, KSA 5.311, PCS).

Ora, aqui percebemos as definições sobre o que Nietzsche entende ser a procedência do direito e da justiça. Contra toda forma de espiritualização e de buscar uma origem metafísica sobre a origem desses fenômenos sociais, mais uma vez vemos o autor descrevê-los como humanos e, portanto, circunscritos historicamente. $\mathrm{Na}$ verdade, aqui o autor permanece fiel às suas teses estabelecidas na primeira dissertação de Genealogia da moral: se, em um primeiro momento, são os nobres que criam os valores, é do pathos da distância "que tomaram para si o direito de criar valores" (GM/GM, I, 2, KSA 5.259, RRTF), o "crédito" da criação da justiça e do direito também deveria recair sobre os nobres. Há uma ideia que surge 
como decorrência desses aspectos: quebra-se a noção metafísica de "justiça em si", que faz com que igualmente seja descartada a ideia um "direito em si".

Seguindo tal lógica, qual seja, de que os nobres possuem o direito senhorial de criar valores, Nietzsche considera que a máxima expressão desse fato é a instituição da lei ${ }^{18}$ que, por conseguinte, acaba por estabelecer o que primariamente seria a relação de "justo" e "injusto". O autor escreve:

Mas o decisivo no que a autoridade suprema faz e impõe contra a vigência dos sentimentos de reação e rancor - o que faz sempre, tão logo se sente forte o bastante -, é a instituição da lei, a declaração imperativa sobre o que a seus olhos é permitido, justo, e proibido, injusto: após a instituição da lei, ao tratar abusos e atos arbitrários de indivíduos ou grupos inteiros como ofensas à lei, como revoltas contra a autoridade mesma, ela desvia os sentimentos dos seus subordinados do dano imediato causado por tais ofensas, e assim consegue afinal o oposto do que deseja a vingança, a qual enxerga e faz valer somente o ponto de vista do prejudicado [...]. Segue-se que "justo" e "injusto" existem apenas a partir da instituição da lei [...]. Falar de justo e injusto em si carece de qualquer sentido; $\mathbf{e m} \boldsymbol{s i}$, ofender, violentar, explorar, destruir não pode naturalmente ser algo "injusto", na medida em que essencialmente, isto é, em suas funções básicas, a vida atua ofendendo, violentando, explorando, destruindo, não podendo sequer ser concebida sem esse caráter (GM/GM II 11, KSA 5.311, PCS).

18 Na teoria do direito, a lei é inserida no debate sobre as fontes do direito. Se recorrermos às definições de Gilissen, temos: “A expressão 'fontes de direito' pode ser entendida pelo menos em três sentidos diferentes: fontes históricas do direito, fontes reais do direito, fontes formais do direito" (Gilissen, 1995, p. 25). As leis compõem, juntamente com os costumes, a jurisprudência e a doutrina, as fontes formais do direito, que são "os instrumentos de elaboração do direito num grupo sociopolítico dado numa época dada; são também os modos ou formas através das quais as normas de direito positivo se exprimem (Gilissen, 1995, p. 26). Apesar de diversas discussões possíveis sobre o conceito de lei e sua historicidade, Gilissen propõe uma definição que, em nosso presente trabalho, cai exatamente no que estamos defendendo: "a lei é uma norma ou um conjunto de normas de direito, relativamente gerais e permanentes, na maior parte dos casos escritas, impostas por aquele ou aqueles que exercem o poder num grupo sociopolítico mais ou menos autônomo" (Gilissen, 1995, p. 27 - destaque nosso). Colocando Nietzsche no debate, poderemos concluir que ele defende a tese de que tanto os costumes como as leis são fontes do direito, mas não encontramos no autor tal detalhamento (de diferenciação entre costume e lei, por exemplo). 
O que notamos, por fim, é a crítica de Nietzsche contra a opinião de alguns autores (aqui nomeadamente Dühring, citado pelo autor nesse e em vários outros momentos) sobre a existência de um "justo" e "injusto" a partir do ato ofensivo (como ofensivo em si mesmo e, consequentemente, a existência de uma "justiça" em si). Ao invés da referência à existência metafísica de uma concepção rígida e fixa de uma justiça "em si mesma", é apenas a instituição da lei, como já pontuado, que define o "justo" e o "injusto". Assim, tendo o direito sido uma criação dos nobres - como aqui viemos defendendo ser a concepção dos textos de Nietzsche - a lei teria sido por eles instituída e, consequentemente, as primeiras concepções sobre o "justo" e o "injusto". Só posteriormente é que tais concepções teriam passado pelo processo da rebelião escrava na moral (cf. JGB/BM 195, KSA 5.117), indicado pelo autor como momento inicial de uma inversão de valores e que ele utiliza tal conceito em sua argumentação na primeira dissertação da Genealogia da moral (cf. GM/GM, I, 7, KSA 5.268).

Até agora, vimos em que medida a relação contratual entre credor e devedor é, nas palavras de Nietzsche, um conceito material de "dívida". Contudo, a questão que se impõe é: afinal, de que modo e por quais procedimentos o conceito material de dívida foi se transformando no conceito moral de culpa? Nesse sentido, Nietzsche argumenta que:

O devedor, para infundir confiança em sua promessa de restituição, para garantir a seriedade e a santidade de sua promessa, para reforçar na consciência a restituição como dever e obrigação, por meio de um contrato empenha ao credor, para o caso de não pagar, algo que ainda "possua", sobre o qual ainda tenha poder, como seu corpo, sua mulher, sua liberdade ou mesmo sua vida [...]. Sobretudo, o credor podia infligir ao corpo do devedor toda sorte de humilhações e torturas, por exemplo, cortar tanto quanto parecesse proporcional ao tamanho da dívida - e com base nisso, bem cedo e em toda parte houve avaliações precisas, terríveis em suas minúcias, avaliações legais de membros e partes do corpo. Já considero um progresso, prova de uma concepção jurídica mais livre, mais generosa, mais romana, que a lei das Doze Tábuas decretasse ser 
indiferente que os credores cortassem mais ou menos nesse caso: "si plus minusve secuerant, ne fraude esto" (GM/GM II 5, KSA 5.299, PCS).

Se, seguindo as exigências do procedimento genealógico, formos verificar a história, encontraremos traços dessa afirmação de Nietzsche em alguns sistemas jurídicos primitivos de alguns povos. Podemos aqui trazer o exemplo da Lei das Doze Tábuas, ${ }^{19}$ citada pelo autor no fim da seção acima indicada. Já de início, podemos realizar uma associação do trecho "algo que ainda 'possua', sobre o qual ainda tenha poder, como seu corpo, sua mulher, sua liberdade ou mesmo sua vida" (GM/GM, II, 5, KSA 5.299, PCS) com a figura do pater famílias do direito romano. O pater famílias é um instituto jurídico do direito romano que sofreu diversas modificações ao longo dos tempos, mas que, segundo Cunha Lobo, "pelas XII Tábuas a família romana continuou a ter como chefe indiscutível o pater famílias, senhor absoluto da casa, exercendo sobre a mulher, os filhos, os escravos, os bens, um poder sem limites". ${ }^{20}$

Além disso, na Tábua Terceira, visivelmente dedicada a tratar dos direitos de crédito, os excertos (4 a 9) trazem o itinerário "processual" de uma cobrança de dívidas. Em resumo, se um devedor não pagar sua dívida, ele pode até ser esquartejado, de modo que seu corpo seja repartido entre seus credores ou pode também ser vendido como escravo. Trazemos o texto, incluindo o trecho que foi citado por Nietzsche:

19 A LEX DVODECIM TABULARVM é datada por volta de 451 a 449 a.C., ou seja, pertence ao direito romano arcaico, especificamente do período da República (que durou de 509 a 27 a.C.). A utilização de exemplos e referências à Lei das XII tábuas e do direito romano em sentido geral, aqui se justifica por duas perspectivas: primeira razão, já descrita, é de que Nietzsche cita exemplos da Lei e por vezes se refere ao direito romano e à história dos romanos. A segunda razão nos vem pelo comentário de Nelson Saldanha: “[...] o Direito Romano teve de certo modo um destino especial perante o desenvolvimento da consciência jurídica ocidental, para servir de ponto de referência histórico. E portanto os problemas históricos tocantes ao Direito Romano surgem como exemplo básico para a questão da utilidade ou inutilidade dos estudos históricos para a ciência do Direito, ou para a questão da natureza do Direito em relação às ciência históricas e às jurídicas" (Saldanha, 1961, p.69).

20 Lobo 2006, p.159. 
4. Aquele que confessa dívida perante o magistrado ou é condenado, terá 30 dias para pagar; 5. Esgotados os 30 dias e não tendo pago, que seja agarrado e levado à presença do magistrado; 6 . Se não paga e ninguém se apresenta como fiador, que o devedor seja levado pelo seu credor e amarrado pelo pescoço e pés com cadeias com peso até o máximo de 15 libras; ou menos se assim o quiser o credor; 7. 0 devedor preso viverá à sua custa, se quiser; se não quiser, o credor que o mantém preso dar-lhe-á por dia uma libra de pão ou mais, a seu critério; 8. Se não há conciliação, que o devedor fique preso por 60 dias, durante os quais será conduzido em 3 dias de feira ou comitium, onde se proclamará, em alta vozes, o valor da dívida; 9. Se são muitos os credores, é permitido, depois do terceiro dia de feira, dividir o corpo do devedor em tantos pedaços quantos sejam os credores, não importando cortar mais ou menos; se os credores preferirem, poderão vender o devedor a um estrangeiro, além do Tibre. ${ }^{21}$

Tais exemplos vão nos direcionando exatamente ao ponto que desejamos abordar: as formas e motivos da utilização do castigo. Antes, contudo, ainda precisamos continuar a compreender a tese de que há uma equivalência entre a dívida e o "causar dor" naquele que deve. A premissa básica dessa questão é a de que "qualquer dano encontra seu equivalente e pode ser realmente compensado, mesmo que seja com a dor do seu causador [...]. [...] a ideia da equivalência entre dano e dor [...]" (GM/GM, II, 4, KSA 5.298, PCS). A dor causada a outro, ou melhor - a dor do devedor causada pelo credor - pode ser compreendida pela seguinte perspectiva: a dor aqui funciona como uma "moeda de troca". Ao invés do pagamento direto da dívida por parte do devedor, o credor se satisfaz com a dor causada por esta dívida, a dor do devedor que empenhou, por exemplo, um pedaço de carne como garantia do pagamento de sua dívida.

São profusos os momentos em que, na sua obra, Nietzsche trata da concepção de equivalência. Tracemos um quadro geral,

21 Meira 1972, p. 169. O destaque no texto é nosso, apenas para nos referenciarmos ao trecho que foi citado por Nietzsche em: GM/GM, II, 5, KSA 5.298-300. A título de indicação história acerca dos institutos jurídicos romanos, é preciso pontuar que essa responsabilidade do pagamento da dívida com o próprio corpo é, mais tarde, mitigada pela Lex Poetelia Papiria (326 a.C.). A partir dela, o débito não mais recai sobre o corpo do devedor: restringe-se apenas ao patrimônio dele (cf. Alves, 2016, pp. 382-436).

Cad. Nietzsche, Guarulhos/Porto Seguro, v.41, n.3, setembro-dezembro 2020|187 
sem a pretensão de esgotar a questão: em Humano, demasiado humano, ele afirma que "A justiça (equidade) tem origem entre homens de aproximadamente o mesmo poder [...]. A justiça é, portanto, retribuição e intercâmbio sob o pressuposto de um poderio mais ou menos igual: originalmente a vingança pertence ao domínio da justiça, ela é um intercâmbio" (MA I/HH I 92, KSA 2.90, PCS). Mais adiante, em Humano, demasiado humano II, $O$ andarilho $e$ sua sombra, ele define:

Equilíbrio [...] é também um conceito muito importante para a mais antiga doutrina legal e moral; equilíbrio é a base da justiça; quando essa, em tempos mais rudes, diz "Olho por olho, dente por dente", pressupõe já alcançado o equilíbrio, e deseja conservá-lo mediante a represália: de modo que, se um indivíduo comete algo contra outro, esse outro já não pratica uma vingança de cego amargor. Mas sim, graças ao jus talionis [lei de talião], é restaurado o equilíbrio das relações de poder contrariadas: pois um olho, um braço mais, naquelas condições primevas, significa um quê de poder, um peso mais (WS/AS 22, KSA 5.555, PCS).

Assim, compreendemos os vários momentos em que Nietzsche faz uma espécie de elogios à "Lei de talião"22: há uma noção de equivalência que é resgatada na sua aplicação. De alguma maneira, há uma relação entre as compensações que o castigo físico provoca àquele que realiza o castigo. Compreendamos a argumentação nietzschiana que vai nesse sentido:

A equivalência está em substituir uma vantagem diretamente relacionada ao dano (uma compensação em dinheiro, terra, bens de algum tipo) por uma espécie de satisfação íntima, concedida ao credor como reparação e recompensa - a satisfação de quem pode livremente descarregar seu poder sobre um impotente, a volúpia de "faire le mal pour le plaisir de

22 Jus talionis é a formulação antiga de uma "regra" jurídica que se estabeleceu em diversos códigos na antiguidade e foi reinterpretada no desenvolver da história. Sua primeira aparição, ao menos que se tem registro, está nos direitos cuneiformes, especificamente no Código de Hammurabi - também citado e elogiado por Nietzsche em diversos momentos. Também há ocorrência do "espírito" dessa máxima no direito romano, na Lei das XII tábuas. O jus talionis refere-se a uma vingança privada, que tem por objetivo estabelecer uma reciprocidade e equivalência entre o dano cometido e a reparação do mesmo, estabelecida pela possibilidade do emprego do castigo físico. 
le faire", o prazer de ultrajar [...] (GM/GM, II, 5, KSA 5.299-300, PCS).

Nietzsche realiza, assim, uma "genealogia da crueldade", que passa a explicar justamente o ponto de ligação do "indissolúvel entrelaçamento de ideias, "culpa e sofrimento" (GM/GM II 6, KSA 5.300, PCS). É apenas retomando a concepção de que em seu estágio mais primitivo o homem exercia livremente sua força, defendida por Nietzsche, que compreendemos essa "moeda de troca". Questiona-se: "em que medida pode o sofrimento ser compensação para a 'dívida'? Na medida em que fazer sofrer era altamente gratificante, na medida em que o prejudicado trocava o dano, e o desprazer pelo dano, por um extraordinário contraprazer: causar o sofrer" (GM/GM, II, 6, KSA 5.300, PCS). É, então, o "prazer na crueldade" que explica o prazer da compensação de uma dívida: através de um pagamento não diretamente relacionado com o objeto da dívida, na medida em que, empenhar o corpo como garantia de uma dívida financeira só resulta em um "autêntico" pagamento, senão de forma indireta. Nesse ínterim, o autor descreve: "Ver-sofrer faz bem, fazer-sofrer mais bem ainda - eis uma frase dura, mas um velho e sólido axioma, humano, demasiado humano [...]" (GM/ GM, II, 6, KSA 5.302 (PCS).

\title{
Philosophy of Right from a genealogical perspective
}

\begin{abstract}
In this article, we investigate the Nietzschean conception of "philosophy of law". Thus, we present the hypothesis that the author has a heterodox concept of the philosophy of law, which can be understood from a genealogical perspective. To put it to the test, we analyzed a posthumous fragment from 1883 in three moments: initially, we presented the Nietzschean critique of Rudolf von Jhering's philosophy of law. In a second step, we indicate that Nietzsche signals a genealogical perspective as a new method for the philosophy of law. Finally, we present what he understands as an example of an interpretative error by legal philosophers: the meaning of punishment.
\end{abstract}

Keywords: On the Genealogy of Morals, philosophy of law, genealogy of law, punishment. 
Gonçalves, Felipe Xavier Luiz

\section{Referências}

ALVES, José Carlos Moreira. Direito Romano. $17^{\mathrm{a}}$ ed. Rio de Janeiro: Forense, 2016.

CAENEGEM, R. C. van. Uma introdução histórica ao direito privado. $2^{\mathrm{a}} \mathrm{ed}$. São Paulo: Martins Fontes, 1999.

DENAT, Céline. Nietzsche, pensador da história? Do problema do "sentido histórico" à exigência genealógica. Cadernos Nietzsche, São Paulo, v. 24, p. 7-42, 2008. Disponível em: https://periodicos.unifesp.br/index.php/cniet/ article/view/7795/5336.

GILISSEN, John. Introdução histórica ao direito. $2^{\mathrm{a}} \mathrm{ed}$. Lisboa: Fundação Calouste Gulbenkian, 1995.

JHERING, Rudolf von. A finalidade do direito. Campinas: Bookseller, 2002.

KOHLER, Josef. “Nietzsche Und Die Rechtsphilosophie.” Archiv Für RechtsUnd Wirtschaftsphilosophie, v. 1, n. 3, p. 355-360, 1907. Disponível em: https://www.jstor.org/stable/23685239? read-now=1\&seq=1\#page scan tab contents.

LARENZ, Karl. Metodologia da ciência do direito. 3. ed. Lisboa: Fundação Calouste Gulbenkian, 1991.

LOBO, Abelardo S. da Cunha. Curso de direito romano: história, sujeito e objeto do direito: instituições jurídicas. Brasília: Senado Federal - Conselho Editorial, 2006.

MEIRA, Sílvio. A lei das XII tábuas: Fonte do direito público e privado. $3^{\text {a }}$. ed. revista e aumentada. Rio de Janeiro: Forense, 1972.

MELO NETO, João Evangelista Tude de; SANTOS, Antonio Carlos de Oliveira. "Convergências e divergências entre Nietzsche e a tradição contratualista moderna: a noção nietzschiana de 'Estado' nas seções 16 e 17 da segunda dissertação de Genealogia da moral". In: Cad. Nietzsche, São Paulo, v. 39, n. 1, p. 31-53, abr. 2018. Disponível em: https://doi.org/10.1590/2316-82422018v3901jetmn.acos.

NIETZSCHE, F. Obras incompletas. Trad. Rubens Rodrigues Torres Filho. São Paulo: Abril Cultural, 1974.

. Sämtliche Briefe. Kritische Studienausgabe (KSB), 8 vols. (Organizada por Giorgio Colli e Mazzino Montinari). Munique/Berlin: Walter de Gruyter, 1986.

190| Cad. Nietzsche, Guarulhos/Porto Seguro, v.41, n.3, setembro-dezembro 2020 
Filosofia do direito em perspectiva genealógica

Sämtliche Werke. Kritische Studienausgabe (KSA), 15 vols. (Organizada por Giorgio Colli e Mazzino Montinari). Munique: Walter de Gruyter, 1999.

. Além do Bem e do Mal: Prelúdio a uma Filosofia do Futuro. Trad. Paulo César de Souza. São Paulo: Companhia das Letras, 2005.

. Humano, demasiado humano. Um livro para espíritos livres. Trad. Paulo César de Souza. São Paulo: Companhia das Letras, 2005.

Humano, demasiado humano. Um livro para espíritos livres II. Trad. Paulo César de Souza. São Paulo: Companhia das Letras, 2008.

Genealogia da moral. Um escrito polêmico. Trad. Paulo César de Sousa. São Paulo: Companhia das Letras, 2009.

. Aurora. Reflexões sobre os preconceitos morais. Trad. Paulo César de Souza. São Paulo: Companhia das Letras, 2016.

PONTES DE MIRANDA, Francisco Cavalcanti. Tratado de direito privado. Tomo XXII. São Paulo: Revista dos Tribunais, 2013.

SALDANHA, Nelson. "A Lei das 12 tábuas e o direito penal romano". In: $\boldsymbol{R} \boldsymbol{e}$ vista Symposium, Recife, v.3, n.1/2, 1961. pp. 68-76.

Enviado: 23/09/2020.

Aceito: 15/10/2020

Cad. Nietzsche, Guarulhos/Porto Seguro, v.41, n.3, setembro-dezembro $2020 \mid 191$ 